\title{
Fotoğrafların Işı̆̆ında Eski Tavşanlı İstasyon Yolcu Binası ve Diğer Tescilli İstasyon Yapılarının Mimari Özelliklerinin Değerlendirilmesi
}

\author{
An Evaluation of the Architectural Features of the Former Tavşanlı Railway \\ Station Building based on Photographs and on Other Registered \\ Station Buildings
}

\begin{abstract}
Sibel YARAR *
Öz: Demiryolu hatları ulaşım tarihinin en işlevsel adımlarından biri olmanın yanı sıra medeniyetin gelişiminde de kilit rol oynayan bir yenilik olmuştur. Demiryolları tarım ve sanayi devrimlerinin sonucu olarak ortaya çıkmıştır. İlk örnekleri Avrupa'da görülen Demiryolları ağı tüm dünyaya dağılmış ve kısa süre sonra Osmanlı topraklarında da kurulmaya başlamıştır. Bu dönemde İngiliz, Fransız ve Alman şirketler tarafından değişik bölgelerde çeşitli güzergahların inşasına başlanmıştır. Cumhuriyet döneminde de hızla devam eden inşa faaliyetlerine gerek yerli gerekse yabancı şirketler vasıtasıyla yenileri eklenerek hatlar arasındaki boşluklar doldurulmuştur. Bu hatlardan biri de Cumhuriyet döneminde oluşturulan Balıkesir-Kütahya hattıdır. Bu hattın ilk etabı olan Kütahya-Tavşanlı arası istasyonları inşası ilk biten bölümdür. Bu çalışmada aynı güzergâh içinde Kütahya ili Tavşanlı ilçesinde yer alan tescilli istasyon binaları fotoğraf ve planlar yardımıyla tanımlanarak değerlendirilmiştir. Günümüzde var olmayan Tavşanlı istasyonu yolcu binasının eski fotoğraflardan yola çıkarak tanımı yapılmış ve aynı hattaki diğer istasyon yolcu binaları ile karşılaştırılarak benzerlikleri ortaya koyulmaya çalışılmıştır.
\end{abstract}

Anahtar sözcükler: Demiryolları, İstasyon Binası, Tavşanlı, Balıkesir-Kütahya Demiryolu

\begin{abstract}
Railway lines that have been a functional step in the history of transportation also have been a key innovation on behalf of an improvement in civilization. Railways were a consequence of the agricultural and industrial revolution. Railways lines which were initally examples in Europe became established shortly after in Ottoman lands. In this period construction works started at various directions in different regions by English, French and German companies. Construction activities were carried out swiftly in the Turkish Republican era by way of both foreign and local companies and gaps between railways lines were completed. One of the railway lines which were established in Republican period is Balıkesir-Kütahya line. The first phase of this line was the Kütahya-Tavşanlı line which was first completed. In this article the registered station buildings of the Tavşanlı railway complex, situated in the Province of Kütahya, is discribed and evaluated. The former Tavşanlı station building is presented and with the assistance provided by old photographs, the Tavşanlı station building is compared to the buildings of other railway stations.
\end{abstract}

Keywords: Railways, Railway Building, Tavşanlı, Balıkesir-Kütahya Railway.

\section{Giriş}

Dünya’da modern anlamda demiryolu inşası Sanayii devriminin ardından gelişen iş kollarının ve üretimin sonucunda doğan taşıma ve hızlı ulaşım ihtiyaçları sonucu ortaya çıkmıştır. 19. yüzyılın ikinci çeyreğinde Avrupa'da inşa edilmeye başlayan demiryolları ağı kısa süre içeri-

* Dr., Sanat Tarihçisi, syarar32@hotmail.com, https://orcid.org/0000-0002-0841-3374 
sinde on binlerce kilometreye ulaşmıştır. Ayrıca bu ağlar kısa süre sonra ülkeler arasında da kurularak hem ticarete hem de yolcu taşımacılığına hizmet etmişlerdir.

İnşa edilen demiryolları genellikle yerleşim merkezleri üzerinde olup bu yollar üzerinde kurulan ana ve ara istasyonlar etrafında yeni yapılaşmaları oluşturmuş ve iskân sahalarını çeşitlendirmiştir (Hasanbat 2018, 9-10).

Osmanlı İmparatorluğu'nun hâkim olduğu geniş topraklarda ulaşım 19. yüzyıla kadar ağırlıklı olarak önemli hatlar üzerindeki kara yolları vasıtasıyla sağlanmış, bu yollara yenileri eklenmiş ve daha az olmak üzere deniz yolundan faydalanılmıştır. 19. yüzyılda ise Batının geliştirdiği yeni ulaşım yolları özellikle Tanzimat Fermanı'ndan sonra Osmanlı topraklarında da uygulanmaya başlanmıştır.

Avrupa devletleri ile yapılan ticari anlaşmalar, uygulamaya koyulan gümrük nizamnameleri, verilen imtiyazlar nedeniyle Osmanlı ile bu devletler arasında farklı ilişkilerin başlamasına sebep olmuştur. Gerek ticari gerek askeri gerekse sömürgelerine ulaşım nedenleriyle Avrupa devletleri Osmanlı'nın ulaşım sisteminde yer almaya önem vermişlerdir. Bu bağlamda limanlar ve demiryolları öncelik kazanmıştır. Tanzimat Fermanı'nda sadece yerli üretime ve imara dair maddeler bulunmasına karşın Islahat Fermanı'nda kara ve suyollarının yeniden yapılmasında Avrupa'nın bilgi ve sermayesine başvurulacağ ifade edilmiştir (Engin 1993, 26-27). Tanzimat döneminden başlamak üzere Abdülmecid, Abdülaziz (özellikle Ali ve Fuat Paşalar) demiryolları ve kanalların açılmasını desteklemişlerdir (Hasanbat 2018, 12).

Osmanlı'da demir yolu kurma ruhsatı ilk defa Abdülaziz döneminde yabancılara verilmiştir. 1856 y1lından itibaren başta İngiltere ve Fransa olmak üzere Almanya ve Amerika'nın da katıldığı pek çok yabancı yatırımcı demiryolu inşa etme ve işletme hakkı için Babı-1 Ali’ye başvurmuştur. $\mathrm{Bu}$ ülkelerin Osmanlı topraklarında yapacakları yatırımlardan beklentileri vardır. $\mathrm{Bu}$ sayede hem kendi teknolojilerini satacaklar, hem Osmanlı topraklarının yeraltı ve yer üstü zenginliklerinden yararlanacaklar hem de sömürgelerine daha kısa süre de ulaşabileceklerdir.

Osmanlı'nın ise yabancı devletlerden farklı olarak demiryollarından kendi beklentileri vardır. İmparatorluğun uzak mesafelerine kadar rahatça ulaşabilmek, denetimi sağlayabilmek, isyanları kolayca bastırabilmek, asker kaçaklarını önlemek, savaş sırasında malzeme ve asker sevkiyatını daha hızlı yapabilmek, ticarette canlılığı arttırmak, Mekke ve Medine'ye ulaşımı rahatça sağlayarak İslam birliğini koruyabilmek, reform yanlılarını memnun etmek, nüfuzunu kaybettiği yerlerde yeniden otorite kurabilmek bunlardan en önemlileridir (Şenyiğit 2002, 21).

Osmanlı İmparatorluğu döneminde inşa edilen demiryollarını şu şekilde gruplamak mümkündür.

1. İzmir ve Çevresindeki Demiryolları

2. Anadolu-Bağdat Demiryolları

3. Hicaz Demiryolları

4. Rumeli Demiryolları

İngiltere hem sömürgesi olan Hindistan'a giden yolu kısaltmak hem de Osmanlı topraklarındaki hammadde kaynaklarından faydalanmak üzere ilk demir yolu inşasını 18511856 yılları arasında İskenderiye-Kahire Hattı üzerinde tamamlamıştır. Bu hat 1869 yılında Süveyş Kanalı'nın aç1lışına kadar önemini korumuştur (Erkan 2007, 20-21).

Osmanlı 1858 yılında demiryolu inşa koşullarını standartlaştırmak için işi almak isteyen şirketlere yönelik altı bölümden oluşan bir şartname hazırlamıştır. Osmanlı'nın Anadolu topraklarında ise ilk demiryolu hattı 1856-1890 yılları arasında İngilizler tarafından yapılan İzmir-Aydın hattıdır. Başlangıçta $130 \mathrm{~km}$ olarak yapılan bu hat daha sonra imtiyazlar vasıtasıyla Dinar'a kadar uzatılmış, bu ana hatta ek olarak Ödemiş, Söke, Denizli ve Çivril'e tali hatlar döşenmiştir 
(Akyıldız 1995, 250-261).

İzmir hattı üzerinde diğer bir demiryolu hattı olan İzmir-Turgutlu İngilizler tarafından 18631866 yılları arasında inşa edilmiş ve bu hat 20. yüzyılın başlarında Afyon'a kadar uzatılarak başta $93 \mathrm{~km}$ olan hat $702 \mathrm{~km}$ uzunluğa erişmiştir (Haykır 2011, 120).

Osmanlı imparatorluk topraklarının Avrupa kısmında açılan ilk demiryolu yine İngiliz sermayesinde yapılmıştır. Köstence-Çernova (Boğazköy) arasında Tuna-Karadeniz hattı olarak adlandırılmış ve 1857-1860 yılları arasında inşa edilmiştir. Bu hatla Rumeli demiryollarının temeli atılmış fakat Osmanlı-Rus Savaşı sonrasında Romanya topraklarında kaldığı için bu ülke tarafından satın alınmıştır (Engin 1993, 40). Rumeli hattının bir kısmının inşası 1869 yılında Paris’te yapılan bir anlaşma ile Avusturyalı Baron Hirsch'e verilmiştir. Mülkiyet Osmanlı üzerinde kalmak üzere kendisine sadece işletme hakkı tanınmıştır. Hirsch ile yapılan anlaşmada kendisine yedi sene içerisinde 2000 kilometreye ulaşacak demiryolu hattı inşası ve ikmali yetkisi verilmiştir. Ana hat İstanbul-Çatalca-Edirne-Harmanl1-Sofya- Niş olup bu hatta Dedeağaç-Yanbolu-Selanik şube hatları bağlanacaktır. 1870 yılında inşaat başlamış ve 1873 yılında bir kısmı tamamlanmış, 1878 yılı sonunda pek çok güzergâh hattı faaliyete geçmiştir. I. Dünya Savaşı sırasında işletme haklarında pek çok değişiklik yapılmış, 1931 yılında ise Türkiye sınırlarında kalan kısmı kurulan yerli şirkete devredilmiştir (Şenyiğit 2002, 29).

Anadolu-Bağdat demiryolları hatt1 1871 yılında Abdülaziz'in imparatorluğun Asya topraklarını İstanbul'a bağlayacak bir demiryolu ağı kurmak için bir ferman yayınlamasıyla gündeme gelmiştir. $\mathrm{Bu}$ fermanda gerçekleştirilmesi düşünülen ana hat İstanbul-Bağdat arasındadır ve bu hat yan hatlarla birlikte Karadeniz, Akdeniz ve Basra Körfezi'ne bağlanacaktır. Bu dönemde Osmanlı ile barışçıl bir politika güden Almanya da demiryolu inşası işine dahil olmuştur. Birkaç ülkenin yatırımcıları ile 1888 yılında bir sözleşme yapılmıştır. Bu uzun süreli bir proje olup ilk etapta İzmir'den Eskişehir yolu ile Ankara'ya kadar bir demiryolu yapımı ve işletmesi ve ileride Bağdat'a kadar uzatılması konusunda anlaşılmıştır. 19. yüzyıl biterken Anadolu-Bağdat hattı dâhilinde kilometrelerce yol döşenmiş ve çoğunluğu Almanlar tarafindan yapılmıştır (Şenyiğit 2002, 31-36).

1871 yılında Üsküdar-İzmit arasında Fransız sermayesi ile demiryolu çalışması başlatılmış bu hattın Haydarpaşa-Pendik arası 1872 'de Pendik-Gebze arası 1873 'te Gebze-İzmit arası ise 1874'de tamamlanmıştır (Sobutay 1996, 6).

Anadolu-Bağdat Demiryolu'nun bir kolunu meydana getiren Güney (Cenup) Demiryolları hattı Toprakkale-Payas-İskenderun, Fevzipaşa-Meydanıekbez, Çobanbey-Nusaybin, ŞenyurtMardin güzergâhlarından oluşmaktadır (Haykır 2011, 123-124).

Kuzey Doğu'da Maden-Yeniköy-Erzurum-Sarıkamış hattı Ruslar tarafından inşa edilmiş ve 1916 yılında işletmeye açılmıştır. Bir süre kullanılan bu hatlar daha sonra devlet tarafindan alınarak sökülmüş ve geniş hat olarak tekrar hizmete açılmıştır.

Tamamıla milli bir inşaat projesi olan Hicaz Demiryolu 1899-1914 yılları arasında gerçekleştirilmeye çalışılan bir icraattır. Aslında bu proje Anadolu ve Bağdat demiryollarını tamamlayıcı bir özelliğe sahiptir. Bu sayede İstanbul'dan Mekke'ye daha hızlı ve güvenli şekilde ulaşılabilecektir. Yapım maksadı dini, askeri ve yönetimsel nedenlere dayanmaktadır. Proje Abdülhamid'in Pan-İslam politikasıyla örtüşen bir düşüncedir. 1900 yılında yayınlanan iradede padişah demiryolunun Şam'dan başlayıp Medine'ye ulaşacak ve Mekke'de sona ereceğini belirtmiştir. Osmanlı'nın hiçbir yabancı devlet karışmadan sadece kendinin yapacağı milli bir proje olacaktır. Fakat işler umulduğu gibi gitmemiş, önce yabancı mühendis, sonra yabanc1 makinalar ve işçiler işin içine girmiş ve Alman nüfuzu çoğalmıştır. Böylece işler hızlanmış ve 1908 yılında Medine'ye kadar ulaşılmıştır. Son aşama olarak Mekke'ye kadar gitmesi düşünüldüyse de gerek Mekke emirinin gerekse bedevi aşiretlerinin direnişleri sonucunda bu hattın 
inşas1 gerçekleştirilememiştir (Şenyiğit 2002, 37-43).

Mütareke dönemine gelindiğinde (1918-1922 ) I. Dünya Savaşı’nın Osmanlı'nın müttefiki olduğu ülkelerin aleyhinde sonuçlanması üzerine imzalanan Mondros Ateşkes Anlaşması ve Sevr Anlaşması'nda demiryolları ile ilgili hükümler de yer almıştır. Bu hükümlere göre imparatorluk topraklarındaki tüm demiryolları sahiplerine devredilecektir. Almanlara ait bütün demiryolları da müttefiklere teslim edilecektir. Osmanlı hükümetinin malı olan demiryolları ise müttefiklere harp tazminatı olarak verilecektir. Böylece demiryolları İngiliz, Fransız ve Yunan işgali altına girmiştir. Anadolu'da istiklal savaşının başlaması üzerine Osmanlının elinde kalan çok az demiryolu önce Eskişehir'de kurulan ve daha sonra Konya'ya taşınan Müdüriyet-i Umumiye teşkilatı tarafından idare edilmiştir (Şenyiğit 2002, 73-74).

Cumhuriyet kurulduğunda elde devlete ait hiçbir demiryolu bulunmamaktadır. Bu nedenle ülkenin yeniden inşasında yeni demir yolları yapmak ve onları işletmek, var olan şirket hatlarını ise satın almak bayındırlıkla ilgili ilk hedefler arasında yer almıştır. Bu anlamda yabancı şirketlerin ellerinde bulunan hatlar, I. Dünya Savaşı sırasında terkedilen topraklarda kalan demiryolları satın alınarak devletleştirilmiştir. 1927 yılından itibaren satın alma işlemleri başlamış 1938 yılına kadar devam etmiştir (Yıldırım 1996, 389-390).

Lozan Anlaşması'ndan sonra 1924 yılında demiryolları siyaseti belirlenmiş ve bu konuda kanunname hazırlanmıştır. Bu anlamda demiryollarını devretmek üzere Anadolu-Bağdat Demiryolları Müdüriyet-i Umumiyesi kurulmuş, yeni demiryolu hatlarının inşası ve işletilmesi için ayrıca üç müdüriyet daha oluşturulmuştur. İki sene sonrasında ise idareyi tek elde toplamak amaciyla bu üç müdüriyet birleştirilerek Devlet Demiryolları ve Limanlar İdaresi Umumiyesi kurulmuştur (As 2006, 94).

Cumhuriyetin yeni demiryolları inşa etme hedefi çerçevesinde 1927 yılında Ankara-Kayseri hattı ile başlamak üzere ilk etapta 1960 yılına kadar Anadolu'da pek çok güzergâh üzerinde yeni demiryolları inşa edilmiştir. Bu inşa süreci günümüze kadar devam etmektedir (Tam liste için: http://www.tcdd.gov.tr/content/31). 1939 y1lında liman işletmesi ile birlikte olan müdürlük Bayındırlık Bakanlığı'ndan alınıp Ulaştırma Bakanlığı'na bağlanmış, 1953 yılından itibaren ise çıkarılan kanunla iktisadi devlet teşekkülü haline gelerek bugün ki ismini (TCDD) almıştır (Ergun 1966, 32-40).

\section{Demiryolu Yapılarının Mimarisi}

Demiryolu istasyonlarının yerleşkesi içerisinde ihtiyaçlardan dolayı çeşitli yapı türleri inşa edilmiştir. Bu yapılar garlar, istasyon yolcu binaları, mal depoları, rıhtımlar, tuvaletler, içme suyu kuyuları, lokomotif depoları, atölyeler, ateş çukurları, su depoları, su kuyuları, kömür rıhtımları, lojmanlar ve ek binalar, alimantasyon binaları, çamaşırhaneler, işçi ve nöbetçi evleridir.

Osmanlı döneminde demiryolu inşaatlarının farklı şirketlere verilmesi bu yollar üzerinde tasarlanan binaların çeşitli üsluplarda yapılmasına neden olmuştur. Yapılar İngiliz, Fransız ve Alman işletmeciler tarafindan inşa edilmiştir. Haydarpaşa, Alsancak, Basmane gibi bazı büyük gar ve istasyon binalarında yapımı üstlenen ülkenin mimari üsluplarının yansımalarını görmek mümkündür. Fransızlar tarafından inşa edilen Basmane Tren Garı Lyon'daki gar binasının yakın bir benzeridir. Bu binalar kagir yapı sistemi ile yabancı mimarlar tarafından inşa edilmiştir. Cumhuriyetin hemen öncesinde bazı Türk mimarların milli üslupta istasyon binaları inşa ettikleri de görülmektedir. Ortak olan nokta plan şemalarının batı modelinde olmasıdır, farklılıklar cephelerde kullanılan yerel ve milli tasarımlarda görülmektedir. İstasyon yapılarının en önemli birimleri gar ve yolcu binalarıdır. Ana hat istasyonlarında inşa edilen gar binaları örneklerinde simetri, anıtsal giriş, kemerli pencere dizileri, kilit taşları, silmeler ve genelde iki yanında birer kule görülmektedir (Demirarslan 2015, 1639). 
Aynı hat üzerinde bulunan bazı istasyon binalarının üslup ve plan bakımından benzerliği gözlemlenmektedir. Örneğin 1873-1880 yılları arasında Osmanlı İmparatorluğu tarafından işletilen Haydarpaşa-Pendik arası yapılan istasyonlardaki bazı yolcu binalarında cephe ve plan tasarımları birbirine benzemektedir. Tasarımlar konut ya da karakol binalarının görünümünü çağrıştırmakta ve böylece halkın yadırgamayacağı bir görünüm vermektedir. Yapılar genelde iki katlı olarak inşa edilen kagir ana yapıya bitişik olarak tasarlanmış tek katlı bir birimden meydana gelmektedir (Erkan \& Ahunbay 2008, 17-18).

Belirli büyük merkezler dışındaki hatlarda ise uygulanmaya çalışılan bir simetri, kagir yapı sistemi ve sıralı pencere dizileri gibi genel tasarımlar dışında belirli bir tipoloji oluşturmak zor görünmektedir. Demiryolu hattı boyunca farklı ihtiyaçları karşılamak üzere çeşitli yapı tipleri inşa edilmiştir. Bu yapılar farklı inşaat etaplarından oluşmaktadır ve değişik zamanlarda inşa edilmişlerdir. İstasyon yerleşkesi içinde yan yana yer alan bu yapılar günümüze kadar değişiklikler geçirmiş ve bir kısmı özgünlüğünü yitirmiştir.

\section{Tavşanlı İstasyonunun Kuruluşu}

Tavşanlı istasyonu Cumhuriyet döneminde projelendirilen Kütahya-Balıkesir güzergâhı içerisinde yer almaktadır. Bu güzergâh Cumhuriyet yönetiminin demiryolları ile ilgili çalışmalarındaki 1924-1927 yılları arasını kapsayan ilk dönem içerisinde yapılmıştır (Fig. 1). Bu güzergâhı inşa etmekteki amaç İstanbul'dan başlayan, İzmit'e ve oradan Eskişehir üzerinden Konya'ya bağlanan Anadolu demiryolları hattını birleştirmektir. Ana güzergâh ile birleşilen nokta Eskişehir-Konya demiryolu hattı üzerindeki Alayunt İstasyonu’dur. Bu istasyondan Kütahya’ya uzanan şube bir hat halihazırda mevcuttur.

1924 yılında güzergâh çalışmaları yapılan hattın ilk etabını oluşturan Kütahya-Tavşanlı için kanun tasarısı hükümet tarafindan Maliye Encümeni'ne sunulmuştur (Fig.2). Encümende ve sonra mecliste kabul edilen bu hat için 16 Nisan 1925 tarihli ve 625 numaralı kanun çıkartılmıştır. 9 Eylül 1925 yılında ise törenle hattın inşasına başlanmıştır. 1927 yılının ortalarına gelindiğinde Kütahya İstasyonu'ndan Demirciören Dură̆ı'na kadar olan inşaat tamamlanmıştır. Bu hat hükümet tarafından Türk müteahhitlere yaptırılmıştır (Haykır 2011, 266).

$\mathrm{Bu}$ kısmın inşasında gerek mali nedenlerden gerekse araç gereç bakımından imkânları kısıtlı Türk firmaları ile sürdürülemeyeceği anlaşılınca hükümet Jullius Berger Şirketi ile 1927 yılında bir anlaşma imzalayarak tüm hattın inşasını bu şirkete vermiştir. Söz konusu şirketi ise Alman Bankalar Sendikası mali yönden destekleyeceğine dair sözleşme kabul etmiş, bir nevi kefil olmuştur. Yapılan anlaşmaya göre şirket Kütahya-Balıkesir hattının inşasına sözleşme tarihinden 45 gün sonra başlayacak ve üç sene içerisinde bitirecektir. Bu anlaşmada sadece hat yapımı değil hat üzerindeki garlar, istasyonlar, depolar ve atölyeler de dahildir. Şirket 1927 yılı içerisinde hem Kütahya hem de Balıkesir tarafından olmak üzere karşılıklı olarak inşaata başlamış Haziran 1928 yılında ise bazı araların ray döşemesi hariç neredeyse bitirmiştir. Aralık ayının ilk günü Kütahya Tavşanlı hattının açılış töreni gerçekleştirilmiştir (Haykır 2011, 266-268).

Fakat bu şirketlerin yerli taşeronlarla anlaşması neticesinde işler istendiği gibi gitmemiştir. Hükümet 1929 yılında çıkarttığı kanunla demiryollarının ödeneğini arttırarak destek vermiştir. $\mathrm{Bu}$ dönemde yabancı şirketlerin taşeronluğunu yapan yerli firmalar avantaj kazanmış ve işlerin pek çoğunu almaya başlamıştır. Hattın Tavşanlı-Değirmisaz bölümü 11 Mart 1930 tarihinde açılmış, 26 Mart 1931 yılında ise Balıkesir ve Kütahya yönlerinden başlayan iki yönlü inşaat birleşerek tamamlanmıştır. Bu arada meydana gelen heyelan nedeniyle bazı hasarlar oluşmuş ve tamirleri neredeyse bir sene sürmüş, resmi açılış merasimi ancak 23 Nisan 1932'de gerçekleştirilebilmiştir (Haykır 2011, 269). 


\section{Tavşanlı İstasyonu Binaları}

İstasyon sahası içinde olan bina sayısı devlet demiryolları kayıtlarına göre yirmi üç yapı görünmektedir. En eski yapı olarak ambar binası yer almakta, diğer yapıların en erken tarihlisi 1950'lerde olmak üzere daha geç tarihlere ait yapılardır. Çoğunluğun yapım tekniği yığma kagirdir. Bunun dışında iki yapı betonarme karkas, biri çelik karkas, bir diğeri ise prefabrik olarak inşa edilmiştir (Fig. 3).

Tavşanlı istasyonun ilk yolcu binası bugün ayakta olmayıp yerinde 1972 yılında inşa edilen yeni bina yer almaktadır. Bugün ayakta olan istasyon binalarından erken tarihli ambar binası, alimantasyon binası ve işçi barakası tescil edilmiş yapılardır.

\subsection{Tavşanlı İstasyonu Eski Yolcu Binası}

Bugün ayakta olmayan Tavşanlı İstasyonu yolcu binasının hattın tamamlandığ 1927-1928 yılları arasında bir tarihte inşa edildiği düşünülmektedir. Planlarına ulaşılamayan yapının elde edilen görsellerinden ortada iki katlı ana bir kütle, yanlarda ise ana kütleye bitişik tek katlı yan kütlelerden oluşan dikdörtgen planlı bir yapı olduğu anlaşılmaktadır (Fig. 4).

Yapının alt katındaki tüm pencere ve kapılar kemerli olarak düzenlenmiş ve etrafları kesme taşlar ile çerçevelenmiştir. Ana kütlenin üst kat pencereleri ise dikdörtgen formdadır. Ana mekânın alt katında güney ve kuzey cepheleri simetrik olmak üzere, bir kapı ve iki penceresi yer almaktadır. Üst katta ise her iki cephede üçer dikdörtgen pencere bulunmaktadır. Yapının iki tarafında yer alan tek katlı kütlelerin boyutlarının aynı olmadığı gözlenmektedir (Fig. 5). Batıda yer alan kısmı daha kısa olup güney ve kuzey cephelerinde birer kemerli penceresi, batı cephesinde ise kemerli bir pencere ve bir kapısı bulunmaktadır. Doğu yönündeki daha uzun olan eklentinin güney ve kuzey yönlerinde geniş açıklıklı birer kapı yer almaktadır. Uzaktan görülen bir fotoğraftan doğu cephesinde ortada küçük bir kare pencere var olduğu anlaş1lmaktadır (Fig. 6). Demiryoluna bakan güney cephesinin önünde trenle aynı seviyeye gelecek şekilde bir yükseltisi olduğu görülmektedir. Bu bölümün başından beri ambar işlevini görecek bölüm olarak yapıldığı açıktır. Bugün ayakta olan ambar binası ise henüz inşa edilmemiştir.

Tavşanlı Yolcu binasının inşasından sonraki tarihlerde çekilmiş bir fotoğraf yapının kuzey cephesi göstermektedir (Fig. 6). Burada yapının batı kısmının değiștirildiği, uzatılarak cephelerine kapılar eklendiği görülmektedir. Doğu cephesi ise ana yapı kütlesinden ayrılmıştır. Muhtemelen ayrılan bu yapı kütlesi bugün hala ayakta olan ambar binasının görünen kısmıdır. Batı cephesine yapılan eklemeyle ambar binasının bugünkü şeklini aldığı düşünülmektedir. Ambar binasının ilk yapılan kısmının çatısı ile sonradan yapılan kısmının çatısı arasında renk farklılığ olduğu da gözlenmektedir.

Bütün bu görsellerden istasyondaki yolcu binasının inşa edildikten sonra tarihi tam olarak bilinmeyen dönemlerde ana kütlenin batısında bulunan bölümün uzatılarak büyütüldüğg̈, doğu kısmında ambar olarak kullanılan bölümün ise önce çatısı ile beraber ana kütleden ayrıldığı ve daha sonra yapılan eklemeyle uzatıldığı anlaşılmaktadır. Yapının 1970 Gediz depreminde gördüğü hasarla yıkıldığı ve yerine 1972 yılında bugünkü binanın yapıldığı bilinmektedir.

\subsection{Ambar Binası}

Ambar binasının inşa tarihine ait bölüm tescil kayıt fişinde boş bırakılmış fakat daha sonra 1897 yılı olarak not edilmiştir. Genel bir kanı olarak da çoğu kez Kütahya Tren İstasyonu'nun kuruluşu ile karıştırılan Tavşanlı İstasyonu'nun yukarıda da belirtildiği gibi Cumhuriyet döneminde yapılan hat üzerinde yer aldığı açıkça görülmektedir.

Tavşanlı İstasyonu'nun eskiden yapıldığını düşündüren bir başka neden de Tunçbilek Maden Ocağı'nın burada yer alması ve bu nedenle çıkan madeni taşımak üzere bir demir yolu ağının çok önceden kurulmuş olması gerektiği fikridir. Tavşanlı'da maden ocakları, özellikle Tunç- 
bilek Maden Ocağı 1906-1907 yılları arasında bulunmuş ve işletilmesine ise daha geç tarihlerde başlanmıştır (Bu konuda geniş bilgi için bk. http://www.gli.gov.tr/eski_tarih.html).

Ambar binası konum itibarı ile demiryolunun ilk sırasında yoldan yaklaşık dört metre içeride ve yola paralel dikdörtgen planda tek katlı bir bina olarak inşa edilmiştir (Fig. 7). Beşik çatı ile örtülü yapının saçakları dışarı taşırılmıştır. Yapının kuzey ve güney yönlerinde simetrik olarak yerleştirilmeyen ikişer giriş kapısı yer almaktadır (Fig. 8). Bu kapılar büyük ve sürgülü ahşap kapılar olarak tasarlanmıştır. Her cephenin iki kapısı arasında çatıya yakın mesafede ikişer küçük pencere yer almaktadır. Aynı pencere düzeni doğu cephenin ortasında da görülmektedir. Ayrıca kuzey ve güney cephenin batı kenarında birer büyük pencere de bulunmaktadır. Kapı ve pencereler basık kemer formunda düzenlenmiştir. Bina yığma moloz taş ile yapılmış ve üzeri sıvanmıştır. Duvar kalınlıkları $50 \mathrm{~cm}$ olup yükseklikler ise kuzey-güney cephelerde yaklaşık 4 $\mathrm{m}$, doğu-batı cephelerde ise en yüksek çatı noktasında $5.60 \mathrm{~cm}$ kadar ulaşmaktadır.

Ambar yapısının eski yolcu binasının doğu yönünde kalan uzantısına ek yapılarak bugünkü şeklini aldığı yukarıdaki bilgi ve fotoğraflardan anlaşılmaktadır. Planda yapının batı cephesindeki ikinci birimin doğu duvarında yer alan girinti de bu bölümün ilk dönemdeki sınırı olarak kabul edilebilecek bir pencere açıklığı yer almaktadır. Daha sonra ilk yapının kuzey cephesinde kalan kap1 ve pencereye uygun tarzda ilaveler yapılarak bir bütünlük oluşturulmuştur. Ambar binasının yolcu binasının bir parçası olarak inşa edilip daha sonraki dönemlerde değişime uğradığı ve en son yapılan ilavelerle birlikte günümüze ulaştığı görülmektedir.

Demiryoluna bakan güney cephede kapılar duvar zemininden $70 \mathrm{~cm}$ yukarıda yer almaktadır. Bu cephede tabandan belirli bir yükseklikte taş görünümlü sıva ile silme yapılmıştır (Fig. 9). Yapının sıvalı duvar yüzeylerinde pencere ve kapılar üç yönden taş örgü ile çerçevelenmiştir. Yapı köşeleri de taş örgü ile şaşırtmalı olarak kaplanmıştır.

İç mekânı orijinalinde büyük ihtimalle bölmesiz tek mekân şeklinde olan ambar yapılan değişikliklerle birisi kendi içinde de bölümlenmekle birlikte beş ana mekâna ayrılmıştır. Bu mekanlar aralara örülen kagir duvarlarla oluşturulmuştur. Güney cephede yer alan iki kap1 içeriden kontraplak ile kapatılarak işlevsiz hale getirilmiştir ve bu nedenle girişler sadece kuzey cepheden sağlanmaktadır.

\subsection{Alimantasyon Binası}

Alimantasyon binası yerleşke içinde demiryolunun kenarında 1956 yılında inşa edilen bir yapıdır. Yapının fonksiyonu buharlı kömür beslemeli lokomatiflere su ikmal etmektir. Bu yapının önceden var olanın deprem sonucu yıkılmasıyla yerine inşa edildiği söylenmektedir (Fig. 10). Yakın çevresindeki diğer gar binalarında da benzerleri görülen yapı kare planlı üç katlı ve alt bölümü yığma taş, üst tarafı ise ahşap malzeme ile inşa edilmiş ve beşik çatı ile örtülmüştür. Yapının köşeleri kesme taş ile şaşırtmalı olarak kaplanmıştır (Fig. 11). Yapının doğu cephesinde basık kemerli bir giriş kapısı yer almaktadır. Bu giriş kapısının üzerinde aynı hizada ve ikinci kat ile üçüncü kat sınırı yüksekliğinde yine basık kemerli bir pencere bulunmaktadır. Batı cephesinde yer alan açılık ise önce kapı olarak düzenlenmiş fakat sonradan pencereye dönüştürülmüş̧ür. Değişim yüzeyindeki kesme taş görünümlü çerçeveden anlaşılmaktadır. Pencere ve kapıların da kenarları taş örgü ile çerçevelenmiştir.

$\mathrm{Bu}$ binadan demiryolundaki lokomotiflere cendereler vasıtasıyla su sağlanmakta iken bugün işlevini yitiren cendereler tren yaylarının ortasında trenlerin yıkanmasında suyu sağlamak için kullanılmakta, alimantasyon binası ise depo işlevi görmektedir.

Yapının içine girildiğinde zemin katın tabanının şap kaplandığı, duvarların ve tavanın sıva üzeri boyalı olduğu görülmektedir. Yine depo olarak kullanılan bir üst kat duvarlar üzerine oturan betonarme kirişlerin taşıdığ tabana sahiptir ve bu mekâna geçiş bir köşeden açılmış boşluğa 
dayanan ahşap gemici merdiveni ile sağlanmaktadır. Duvarları ve tavanı sıva üzeri boya yapılmış bu kattan duvarları ve tavanı ahşap, döşemesi ise betonarme olan son kata yine aynı şekilde merdivenle ulaşılmaktadır. Bu katın ortasına su deposu yerleştirilmiştir. Marsilya kiremidi ile örtülü çatının saçakları doğu ve batı cephelerde yapı bünyesinden dışa taşmaktadır.

\section{4 İşçi Barakası ( Lojman )}

1967 yılında inşa edildiği bilinen yapı, üzeri sıvalı kagir bir bina olarak yapılmıştır. Yapı biri tek diğeri iki katlı olmak üzere birbirine bitişik olarak yapılmış iki binadan oluşmaktadır. Her iki yapı beşik çatı ile örtülmüştür (Fig.12). Dikdörtgen planlı ve tek katlı olan bina işçi barakası olarak kullanılmış, bu yapıya bitişik olarak inşa edilen iki katlı ve dikdörtgen planlı diğer bina ise lojman olarak düşünülmüştür.

Tek katlı olarak inşa edilen işçi binasına güney cepheden iki kapı ile giriş sağlanmaktadır. Güney cephesinde dört adet üzeri taş söveli penceresi yer almaktadır (Fig.13). Kuzey cephesinde ise üç büyük üç küçük pencere bulunmaktadır ve bu pencereler güneydekilerin aksine sövesizdir. İç kısmı orijinalliğini tamamen kaybetmiş olup günümüzde ihtiyaca yönelik olarak çeşitli bölümlere ayrılmıştır.

Batı cephesindeki kapılardan sağındakinden girildiğinde depo olarak kullanılan mekâna ulaşılmaktadır. Sol kapıdan girildiğinde bir hole rastlanmaktadır. Bu holden ise yatakların bulunduğu odalara geçilmektedir. Yapının doğu cephesinde girişi olan lojman kısmının bu cepheye açılan alt ve üst katta birer penceresi yer almaktadır. Aynı pencere düzeni kuzey cephesinde de görülmektedir. Bu cephe tasarım olarak iki kütleye ayrılmış, güneyde kalan bölüme sadece pencere açıklıkları yerleştirilmiş, kuzeydeki bölüm ise daha içeride tutularak giriş kapısı açılmıştır (Fig.14). Yapının hem tek katlı ve iki katlı kısmı ayrı haneler olarak tasarlanmış ve içleri orijinalliğini yitirerek ihtiyaçlara göre yeniden düzenlenmiştir.

\section{Tavşanlı İstasyon Yapılarının Değerlendirilmesi ve Karşılaştırılması}

Ele aldığımız Tavşanlı İstasyonu binaları hakkında elde edilen bilgiler oldukça sınırlıdır. Yapıların ilk durumlarını gösteren detaylı fotoğraf bulunamadığından ilk görünümleri hakkında kesin bir şey söylemek güçtür. Bunula birlikte yapılan analizlerden kullanılan malzeme ile ilgili bilgiler edinebilmek mümkün olmuştur. Yapıların iç mekanları sayısı ve detayları bilinmeyen tarihlerde restorasyon geçirmiş ve orijinalliklerini tamamen kaybetmişlerdir. Dış cepheler de ise yapıları özellikli kılan kapı ve pencere etrafındaki taş silme söveler hala mevcuttur. Bu özellikler demiryolları hatlarındaki diğer pek çok yapıda da kullanılan karakteristik özelliklerdir.

Tavşanlı İstasyonu Yolcu Binası günümüzde ayakta olmasa da fotoğraflarından anlaşılacağı üzere diğer pek çok istasyondaki yolcu binası gibi ana kütlesi iki katlı olan ve iki tarafına değişik işlevlerle eklenmiş birer tek katlı yan kütleden oluşan bir planlama ile yapılmıştır. Ana kütlenin giriş katı yolcu bekleme salonu olarak kullanılmakla birlikte değişik işlevlere yönelik bazı bölümler de yer alabilmektedir. İlk yapıldığı zamanlarda muhtemelen üst kat lojman olarak değerlendirilmiş olmalıdır. Çünkü istasyon binalarının inşası değiş̧ik dönemlerde tamamlanmakta, öncelikle gerekli olan birimler yapılıp daha sonra yerleşke içinde sırayla eksiklikler tamamlanmaktadır. Yolcu binasının doğu yönüne bitişik olarak yapılan ve tren raylarının bulunduğu güney cephesindeki kapısının önü yükseltilen bölümün başından itibaren istasyonun ambar binası olarak kullanılmak üzere tasarlandığını göstermektedir. Bat1 yönündeki ek bölüm ise bilet gişesi ya da farklı bir işlevde kullanılmak üzere değerlendirilmiş olmalıdır.

Balıkesir-Kütahya hattı üzerinde yer alan Tavşanlı istasyonu bir ara istasyondur. Bu nedenle Balıkesir ve Kütahya istasyon yolcu binaları gibi büyük bir yapı özelliği göstermemektedir. Bu ana hat üzerinde bulunan ve günümüze ulaşan diğer tarihi ara istasyon yolcu binalarına bakıld1ğında hepsinin aynı plan tipinde yapıldığı gözlenmektedir. Bu hat üzerinde bulunan Köprüören 
(Fig. 15), Nusrat (Fig.16), Dursunbey, Balıköy istasyonları yolcu binalarının Tavşanlı İstasyonu yolcu binası ile aynı planda oldukları görülmektedir. Görsellerden de anlaşılacağı üzere ara istasyonlar bir tip proje ile yapılmıştır. Mezitler, Değirmisaz gibi bazı istasyon yolcu binalarının ise yıkılma ya da tamir sonucu özelliklerini yitirdikleri gözlenmektedir.

Ambar binası diğer pek çok istasyonda olduğu gibi amacı gereği demiryolu platformuna paralel olarak en yakın mesafede inşa edilmiştir. Yapım tekniği yığma taş olmasına rağmen üzeri sıvanmıştır. Kapı ve pencere söveleri, taş örgü görünümlü çerçeveleri ve yapı köşelerindeki kesme taş örgüsü ince bir tabaka şeklinde beyaz sıva ile yapılmıştır.

İstasyon binaları arasında yer alan Ambar binaları istasyondaki diğer binalar gibi belirli karakteristik özelliklere sahiptir. İşlevlerinden dolayı hemen hepsi demiryolu raylarına paralel olarak ve raylara en yakın mesafede konumlanmışlardır.

Plan olarak hemen hepsi uzun dikdörtgen formundadır ve cephede geniş açılıkları olan birkaç kapıya sahiptir. Bu kapı ve pencereler istasyondaki pek çok binada olduğu gibi taş ya da taş görünümlü sıva silmeleriyle çevrelenmiştir. Yapı köşeleri de aynı şekilde kesme taş ya da taş görünümlü sıva ile vurgulanmıştır. Kap1 ve pencereler çoğunlukla basık kemerlidir. Üst örtü ise beşik çatılı olup dışarı çıkma yapan geniş saçaklar yer almaktadır.

Malzeme olarak çoğunlukla yığma moloz taş kullanılan yapılar sıva ile kapatılmış ve boyanmıştır. Pek çok bölgede özellikle aynı hattı takip eden istasyonlarda binaların sarıya boyandığı ve kapı, pencere ve köşe silmelerinin beyaz renkte tasarlandığı görülmektedir.

Yukarıda saydığımız özellikler sonradan inşa edilen Balıkesir-Kütahya arası hattında olduğu kadar inşa tarihi eski olan Alayunt-Afyon hattı üzerinde de görülebilmektedir.

Tavşanlı İstasyonu'na en yakın mesafede bulunan Kütahya istasyonunda yer alan ambar binası genel çerçevede aynı özellikleri taşımaktadır (Fig. 17). Benzer tasarım örneklerini Karabük ve Saltukova tren istasyonlarındaki ambar binalarında görmek mümkündür. Tavşanlı İstasyonu alimantasyon binası işlevini uzun süre önce yitirmiș olup günümüzde depo olarak kullanılmaktadır. Sadece zemin katının kullanılması yapının diğer bölümlerinin atıl duruma düşmesine sebep olmuştur.

Tren istasyonlarında o dönemde kullanılan buharlı lokomotiflerin su ihtiyacını karşılamak üzere yapılmış alimantasyon binaları işlevleri gereği hemen hepsi aynı tarzda yüksek binalar olarak yapılmışlardır. Bu tür yapılar genelde kare ya da kareye yakın dikdörtgen planlı, üç ya da dört katlıdırlar. Yapı malzemesi olarak alt katlarda yığma taş kullanılmış, köşeler kesme taş ya da bu görünümü veren sıvalarla kaplanmış, en üst kat ise ahşap olarak inşa edilerek beşik çatı ile örtülmüsşür. Cephelerde genelde katları dışarıya yansıtan silmeler yer almaktadır. Genelde bir giriş kapısına sahip olan binada pencere sayısı az olup bunlar özellikle giriş ve karşı cephe de bulunmaktadır. Katlar arasına geçiş genelde yapı içinde, tavanın bir köşesinde bırakılan açıklığa yerleştirilen müstakil bir merdivenle sağlanmaktadır. Ara katlar değişik işlevler için kullanılmakla birlikte üst kat suyun depolandığı mekandır.

İstasyonların inşa edildiği dönemde yapılması gerekli olan bu binalar genelde yolcu binası ve ambarların olduğu bölümden ayrı, fakat demir raylarına yakın mesafede bir yerde konumlanmıştır. Türkiye'nin çeşitli bölgelerinde karakteristik özellikleri bakımından birbirine çok benzeyen planda inşa edilen yapılar kat sayıları farklı olmak üzere özellikle son kattaki ahşap bölümü ile karakteristiktir. Tavşanlı istasyonu alimantasyon binasına en yakın örnekler olarak Kütahya (Fig. 18) ve Alayund istasyonlarındaki alimantasyon binaları örnek verilebilir Kat sayısı ve cephedeki silmeler gibi detaylar farklı olsa da ilk bakışta alimantasyon binası olduğunu vurgulayan kütlesi ve özellikle ahşap katıyla birbirini andırmaktadır. Dış yüzeylerdeki farklılıkların bir kısmı yapıların daha sonraki dönemlerde geçirdiği onarımlardan kaynaklanmaktadır. Demiryolları istasyonlarının pek çoğunda bugün hala ayakta olan bu yapılar karakteristik 
özelliklerinden dolayı ilk bakışta tanınabilmektedir (Fig. 19).

Tavşanlı İstasyonun demiryolu hizasındaki sırada yer alan işçi barakası istasyon içerisinde çalışan görevlilerin barınma ihtiyacını karşılamak üzere yapılmış pek çok yapı türünden biridir. İstasyon alanı içinde genellikle istasyonun büyüklügüne göre çalışanlara ayrılan bir ya da birden fazla lojman ya da işçi evi bulunmaktadır. Bu yapılar genellikle istasyonun ilk sıralarında olmak üzere diğer binalardan ayrı bir yerde inşa edilmiştir. İç mekanları ihtiyaçlara göre bölümlenmiş olan bu yapıların dışı genellikle diğer istasyon binalarında olduğu gibi yığma taş üzeri sıva kaplamalıdır. İstasyon içindeki diğer yapılarla aralarındaki benzerlik pencere ve kapılar üzerindeki silmeler, beşik çatı ve saçaklardır. Pencere ve kapılar bazen kemerli bazen ise düzdür fakat özellikle üst kısmını çevreleyen silmeleri mevcuttur. Demiryolları güzergâhında bulunan istasyonlarda yer alan lojman ve işçi evlerinde bu özellikleri görmek mümkündür. En yakın örnekleri olan Kütahya (Fig. 20), Alayund ve Afyon İstasyonu lojman binalarında da benzerlerine rastlanılmaktadır.

\section{Sonuç}

Demiryollarının Anadolu'da kurulmaya başladığı 19. yüzyılın ortalarından itibaren hatlar büyük bir hızla çoğalmış ve 20. yüzyılın başına gelindiğinde 700 km'ye ulaşmıştır. Hem askeri, hem politik hem de ticari amaçlarla inşa edilen bu demiryolları çoğunlukla yabancı sermaye ile yapılmış, gerek malzemeler gerekse uygulayıcı kadro yurt dışından getirilmiştir. Başta İngiliz olmak üzere Fransız ve Alman şirketler tarafından inşa edilen istasyon yapılarında dönemin ve yapan ülkenin mimari tarzından izler görülmektedir.

Demiryolu istasyonlarında başta yolcu binaları olmak üzere, ambar, hangar, alimantasyon binası, bekçi kulübeleri, lojmanlar, lokomotif depoları, tuvaletler gibi pek çok yap1 yer almaktadır. Bu yapıların bir kısmı yıkılmış, bir kısmı tamir görmüş, bir kısmı ise sağlam olarak günümüze kadar ulaşmıştır. Yapıların iç kısımlarının ise tamamen yenilendiği görülmektedir. İstasyon binalarının karakteristik özellikleri olan cephe düzenlemeleri çoğunlukla korunarak günümüze kadar gelmiştir. Bu özellikler; moloz taş üzeri sıva, kesme taş çerçeveli köşeler, genelde basık kemer şeklinde olmak üzere bazı yerlerde sivri kemer, pencere ve kapı kenarlarının silmeli söveleri, özellikle kapıların kesme taş ve ya taş görünümlü sıva ile şaşırtmalı olarak çerçevelenmesi, üzeri Marsilya kiremidi ile örtülü beşik çatı, geniş saçaklar, cephe boyunca devam eden silmelerdir. Bazı bölgelerde taşın kendi rengi kullanılmakla birlikte çoğunluğunda uygulanan sarı boya ve beyaz çerçeveler bu yapıları ilk bakışta tanımlayan önemli bir özelliktir.

Araştırmaya konu olan Tavşanlı istasyon yapıları içinde yer alan ve günümüzde var olmayan yolcu binasının diğer ara istasyonlardaki binalarla aynı özelliklere sahip bir yapı olarak bu hat üzerinde uygulanan tip projenin bir parçası olduğu görülmektedir. Ambar binası ilk yapıldığında istasyon yolcu binasının bir yan kütlesi olarak tasarlanan küçük bir yapı iken daha sonra ana kütleden ayrılıp müstakil bir hale gelmiş ve yapılan eklemeyle büyütülmüştür. Dış görünüşü ile istasyon yerleşkelerinde yer alan diğer pek çok ambar ile aynı özellikleri gösteren yapı tipinin karakteristik özelliklerini taşımaktadır. Yakın tarihlerde yeniden inşa edilen Alimantasyon binası istasyon sahalarında ilk yapılışından bu yana varlığını sürdüren örnekleri ile uyumlu karakteristik özelliklere sahip olarak tasarlanmıştır. Her istasyonda yer alan ve sayıları ihtiyaca göre değişiklik gösteren lojman (işçi evi) binası dış görünüşüyle yerleşkedeki diğer yapılarla bir bütünlük göstermektedir. Mevcut olan tescilli binalar görünüm itibarı ile yukarıda saydığımız genel özellikleri bünyelerinde barındıran ve böylece istasyon yapısı geleneğini geçmişten günümüze taşıyan ve geleceğe aktarılacak olan önemli birer temsilcidir. 


\begin{tabular}{l|l|l} 
Yapılan Hat Kısımlanı & Yapııı̧ Tarihi & Kilometre \\
\hline Ankara-Kayser & 28.05 .1927 & 381 \\
Kayseri-Sivas & 30.08 .1930 & 223 \\
Samsun-Kalın & 31.08 .1932 & 380 \\
Irmak-Zonguldak & 12.11 .1935 & 416 \\
Sivas-Erzurum & 23.11 .1938 & 332 \\
Erzincan-Erzurum & 20.10 .1938 & 215 \\
B.Köprü-K. Gediği & 02.05 .1933 & 172 \\
Kütahya-Balıkesir & 23.04 .1932 & 253 \\
Fevzipaşa-Diyarbakır & 23.11 .1935 & 505 \\
Yolçatı-Elazı̆̆ & & 24 \\
Malatya-Çatinkaya & 16.08 .1936 & 140 \\
Afyon-Karakuyu & 25.03 .1936 & 113 \\
Maladız-Burdur & 1936 & 24 \\
Bozanönü-lsparta & 26.03 .1936 & 14 \\
Köprüağzı-Maraș & 1948 & 28 \\
Narlı-Gaziantep & 1953 & 85 \\
Elazı̆̆-Muş & 1955 & 241 \\
Diyarbakır-Kurtalan & 1944 & 160 \\
Gaziantep-Karkamış & 1960 & 91 \\
& &
\end{tabular}

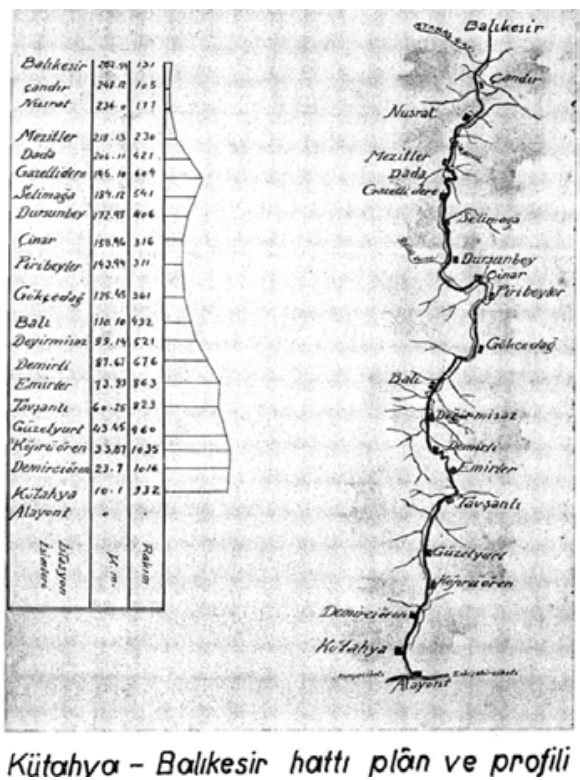

Fig. 1. Cumhuriyet Döneminde İnşa Edilen Anadolu Demiryolları Hatları(Şenyiğit 2002, 77).

Fig. 2. Kütahya-Balıkesir Hattı Planı (Haykır 2011, 273).

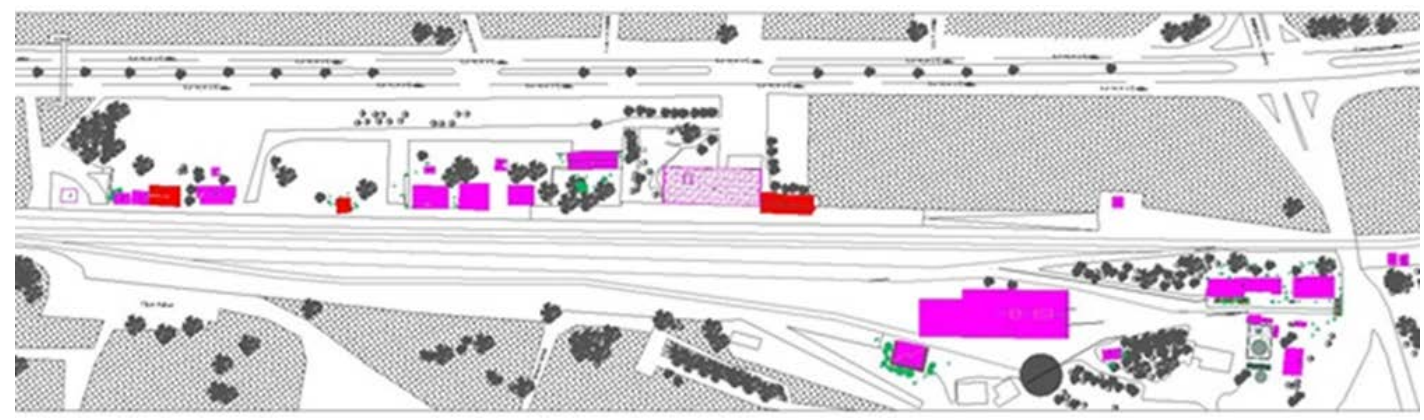

Fig. 3. Tavşanlı Gar Yerleşkesi (Tescilli Yapılar Kırmızı Renktedir, dad Mimarlık

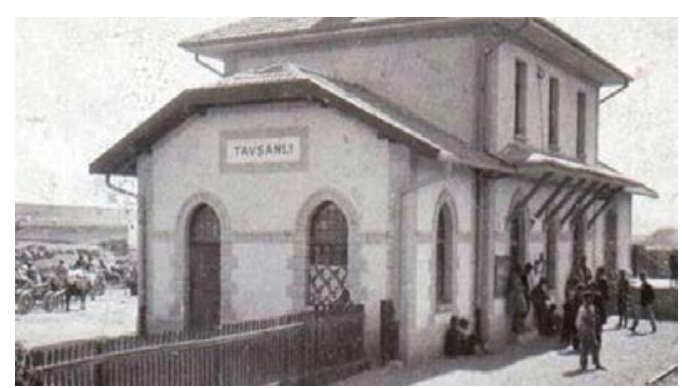

Fig. 4. Tavşanlı İstasyonu Eski Yolcu Binasının 1939 Tarihli Genel Görünüşü (Tavşanlı Belediyesi Fotoğraf Müzesi Arşivi).

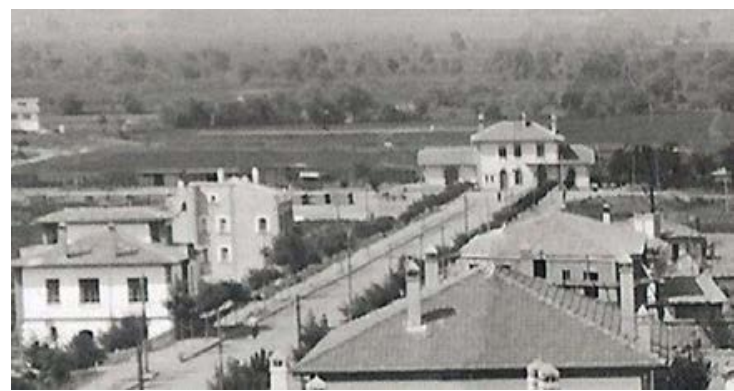

Fig. 5. Tavşanlı İstasyon Caddesinin Sonunda Tavşanlı İstasyon Yolcu Binasını Gösteren 1941 Tarihli Fotoğraf (Tavşanlı Belediyesi Fotoğraf Müzesi Arşivi). 


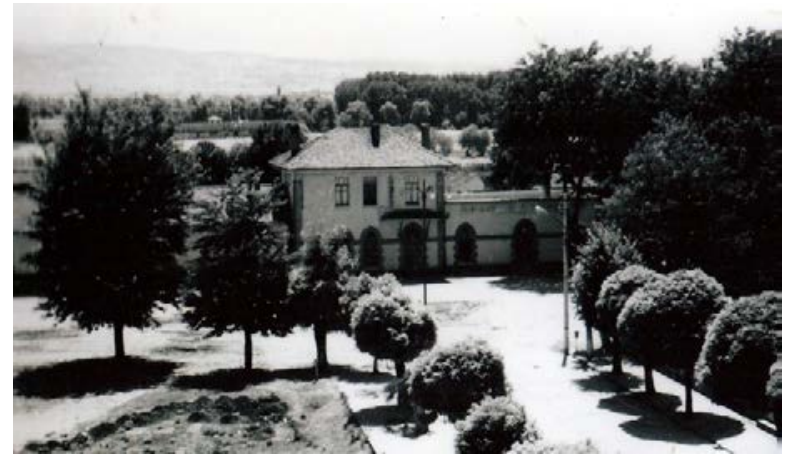

Fig. 6. Tavşanlı İstasyonu Yolcu Binası Kuzey Cephesine Ait 1940 Tarihli Fotoğraf (Tavşanlı Belediyesi Fotoğraf Müzesi Arşivi).

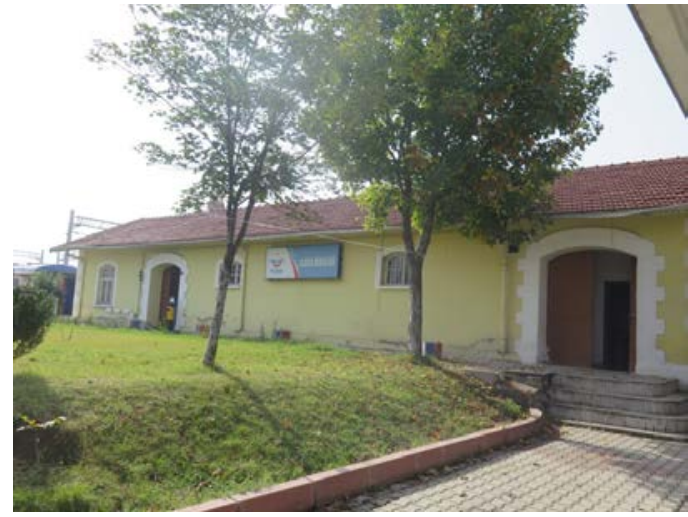

Fig. 8. Tavşanlı İstasyonu Eski Yolcu Binasının 1939 Tarihli Genel Görünüşü (Tavşanlı Belediyesi Fotoğraf Müzesi Arşivi).

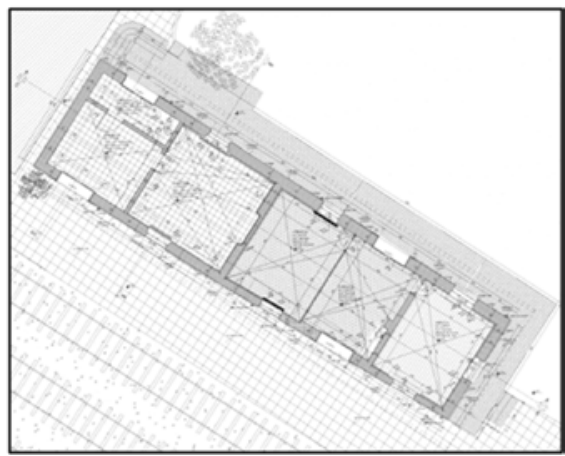

Fig. 7. Tavşanlı İstasyonu Ambar Binası Planı (dad Mimarlık).

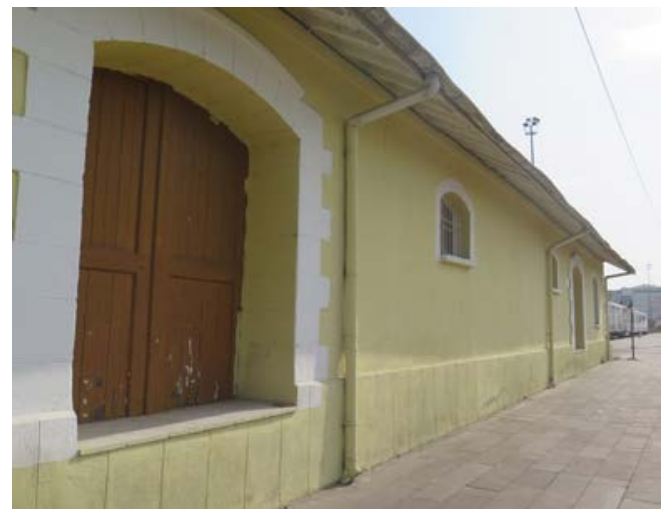

Fig. 9. Tavşanlı İstasyon Caddesinin Sonunda Tavşanlı İstasyon Yolcu Binasını Gösteren 1941 Tarihli Fotoğraf (Tavşanlı Belediyesi Fotoğraf Müzesi Arşivi).

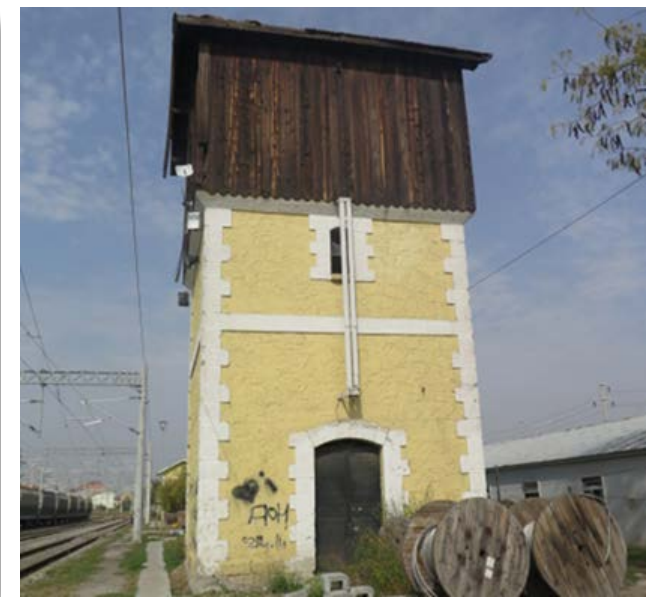

Fig. 10-11. Tavşanlı İstasyonu Alimantasyon Binası Planı (dad Mimarlık) ve Doğu Cephesi Fotoğrafi (16 /10/2018). 


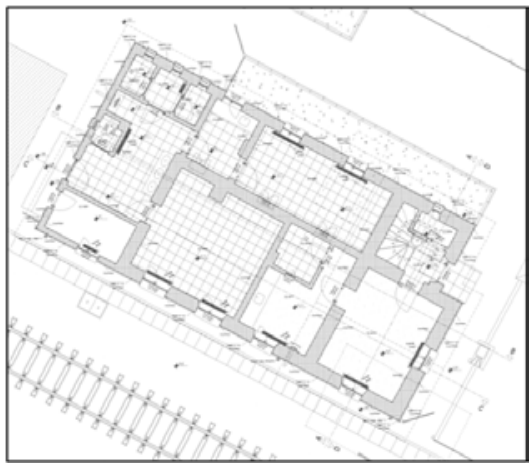

Fig. 12. Tavşanlı İstasyonu İşçi Barakası Zemin Kat Planı (dad Mimarlık).
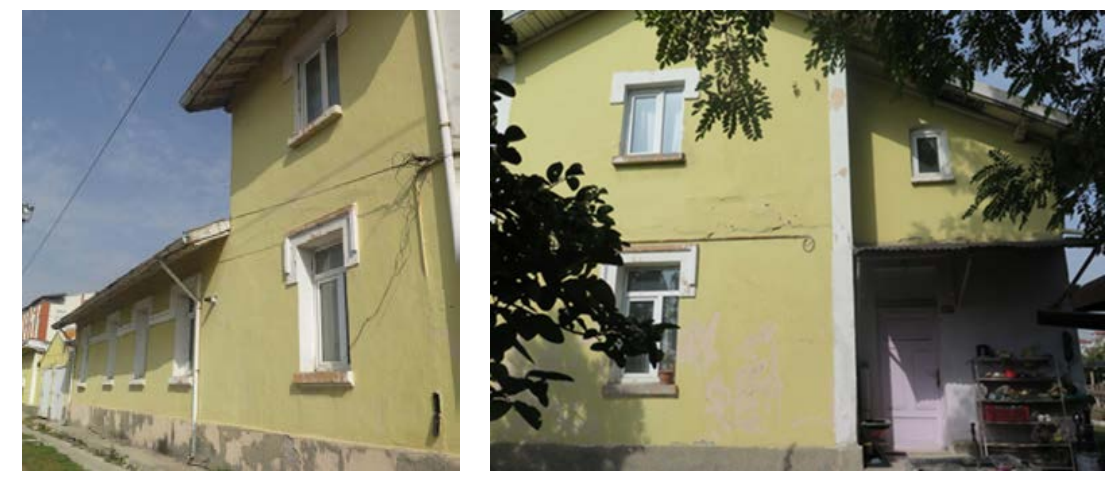

Fig. 13-14 Tavşanlı İstasyonu İşçi Barakası Güney ve Doğu Cepheleri $(16 / 10 / 2018)$.

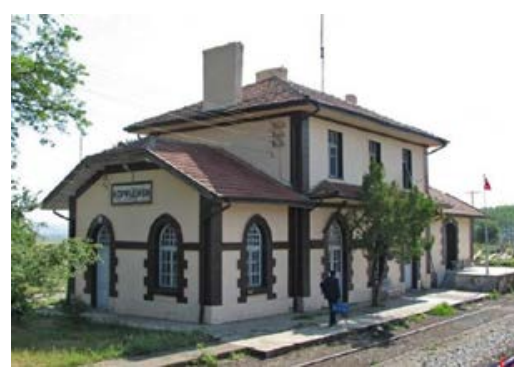

Fig. 15. Kütahya-Tavşanlı Hattı üzerinde Yer Alan Köprüören İstasyonu Yolcu Binası (Google).

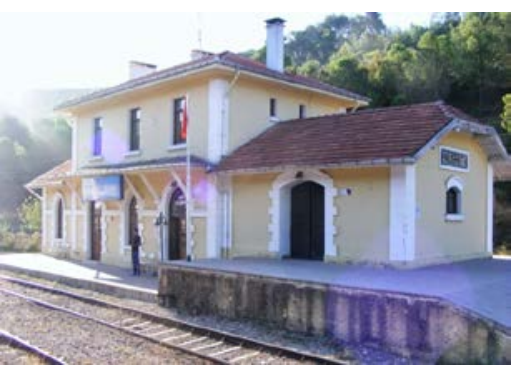

Fig. 16. Kütahya-Tavşanlı Hattı üzerinde Yer Alan Nusrat İstasyonu Yolcu Binası (Google).

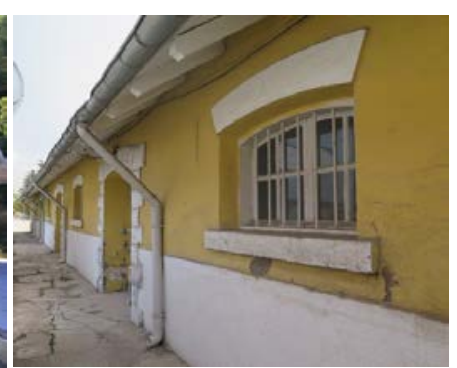

Fig. 17. Kütahya İstasyonu Tescilli Ambar Binası Genel Görünüş (16/10/2018).
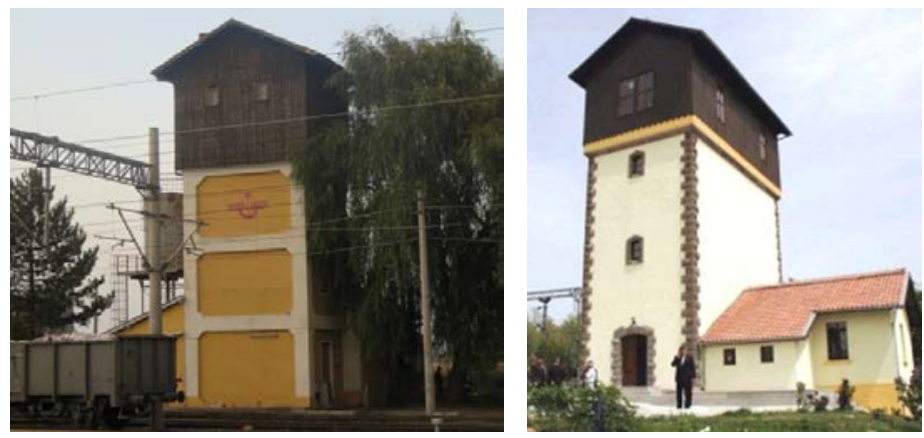

Fig. 18-19. Kütahya (16/10/2018) ve Çankırı Çerkeş (Google) İstasyonlarındaki Alimantasyon Binaları.

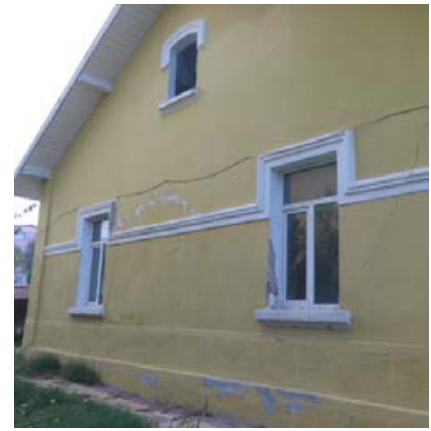

Fig. 20. Kütahya ve Afyon İstasyonları Lojman Binaları (16/10/2018). 


\section{KAYNAKÇA}

Akyıldız A. (1995). “Osmanlı Anadolusunda İlk Demiryolu: İzmir Aydın Hattı (1856-1866)”. Ed. E. İhsanoglu. Çă̆ını Yakalayan Osmanlı (1995) 249-271. İstanbul.

As E. (2006). Cumhuriyet Dönemi Ulaşım Politikaları (1923-1960). Yayımlanmamış Doktora Tezi. Dokuz Eylül Üniversitesi. İzmir 2006.

Demirarslan D. (2015). "Batılılaşma/Modernleşme Dönemi Demiryolu Politikası ve İstasyon Binası Mimarisi: İzmit ve Hereke Tren İstasyonları”. Uluslararası Gazi Akçakoca ve Kocaeli Tarihi Sempozyumu (2015) 1635-1649.

Engin V. (1993). Rumeli Demiryolları. İstanbul 1993.

Ergun M. (1966). Milli Demiryollarımızın Kısa Bir Tarihçesi. İstanbul 1966.

Erkan Y. K. (2007). Anadolu Demiryolu Çevresinde Gelişen Mimari ve Korunması. İstanbul 2007.

Erkan Y. K. \& Ahunbay Z. (2008). “Anadolu Demiryolu Mirası ve Korunması”. ITÜ Dergisi 7/2 (2008) 14-25.

Hasanbat B. (2018). Edirne-Kırklareli-Tekirdă̆ İlleri Sınırları Dahilindeki Tarihi İstasyon Binaları. Yayımlanmamış Yüksek Lisans Tezi. Erciyes Üniversitesi. Kayseri 2018.

Haykır Y. (2011). Atatürk Dönemi Kara ve Demiryolu Inşa Çalışmaları (1923-1938). Yayımlanmamış Doktora Tezi. Fırat Üniversitesi. Elazı̆̆ 2011.

Sobutay G. L. Ç. (1996). Türkiye’de İstasyon Yapılarının Geçmişten Günümüze Değişmesi. Yayımlanmamış Yüksek Lisans Tezi. Gazi Üniversitesi. Ankara 1996.

Şenyiğit Ö. (2002). Adana-Mersin Demiryolları Hattı Üzerindeki İstasyon Binalarının Tarihi ve Mimari Analizi. Yayımlanmamış Yüksek Lisans Tezi. Çukurova Üniversitesi. Adana 2002.

Yıldırım İ. (1996). “Atatürk Dönemi Demiryolu Politikasına Bir Bakış”. Atatürk Kültür, Dil ve Tarih Yüksek Kurumu Atatürk Araştırma Merkezi Dergisi (ATAM) (1996) 387-395.

\section{Elektronik Kaynaklar}

http://www.tcdd.gov.tr/content/31

http://www.gli.gov.tr/eski_tarih.html. 